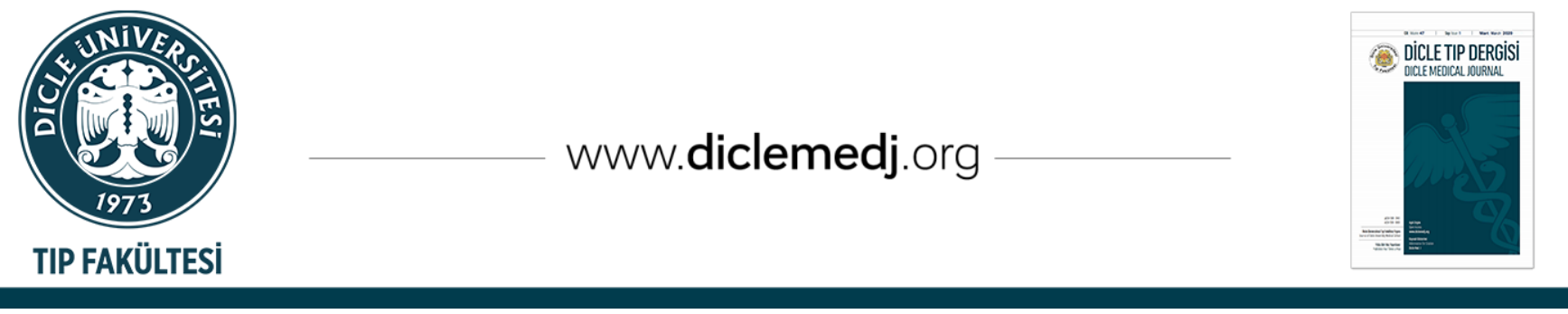

Case Report / Olgu Sunumu

\title{
Nodular Lymphocyte Predominant Hodgkin Lymphoma With Sarcoid- Like Granulomas: A Rare Association
}

\author{
Monika Gupta ${ }^{\text {D } 1}$, Nilay Nishith ${ }^{1 D}$, Ruchika Majoka ${ }^{\text {iD }}{ }^{1}$, Meenu Gill ${ }^{D}{ }_{1}$, Rajeev Sen ${ }^{1} 1$
}

1 Department of Pathology, Pt. BDS, PGIMS, University of Health Sciences, Rohtak, India

Received:14.02.2020;Revised:24.05.2020;Accepted:30.05.2020

\begin{abstract}
Granulomatous inflammation is commonly seen in Hodgkin lymphoma. However; the recent literature fails to correlate the subtypes of HL with granuloma. An occasional report describes association of mixed cellularity classical Hodgkin lymphoma with granulomatous reaction. None of other variants of HL are known to manifest with granulomatous reaction. We report a 34-year-old female patient who presented with swelling in right under arm for four months with no history of fever or weight loss. Fine needle aspiration cytology of axillary swelling revealed reactive lymphadenitis. To confirm the diagnosis lymph nodes excision was performed. Histomorphological examination revealed effacement of lymph node architecture by small to intermediate sized lymphoid cells with interspersed mononuclear Reed Sternberg cells like cells along with confluent and discrete non caseating granulomas. Additionally, immunohistochemical staining was performed, which rendered a diagnosis of nodular lymphocyte predominant Hodgkin lymphoma with granulomatous inflammation. This association is uncommon thereby making it pertinent for us to report this rare pathological entity also emphasis on careful microscopic evaluation of lymph node particularly with granulomatous reaction.
\end{abstract}

Keyword: Hodgkin lymphoma, Granuloma, Sarcoidosis, Fine needle aspiration cytology

DOI: $\mathbf{1 0 . 5 7 9 8 / \text { dicletip.755782 }}$

Correspondence / Yazışma Adresi: Monika Gupta, 17/8 FM, Medical enclave ,PGIMS, Rohtak, Haryana, Indiae-mail: monikashashwat@hotmail.com 


\section{Sarkoid Benzeri Granülomlu Nodüler Lenfosit Baskın Hodgkin Lenfoma: Nadir Bir İlişki}

\section{Öz}

Granülomatöz inflamasyon Hodgkin lenfomada yaygın olarak görülür. Ancak; son literatür HL alt tiplerini granülom ile ilişkilendirememektedir. Nadir bir raporda, karma hücresel klasik Hodgkin lenfoma ile granülomatöz reaksiyon arasındaki ilişki açıklanmaktadır. Diğer HL varyantlarının hiçbirinin granülomatöz reaksiyonla ortaya çıktığı bilinmemektedir. Ateş ya da kilo kaybı öyküsü olmayan dört ay boyunca sağ kol altında şişlik şikayeti ile başvuran 34 yaşında bir kadın hastayı sunuyoruz. Aksiller şişliğin ince iğne aspirasyon sitolojisinde reaktif lenfadenit saptandı. Tanıyı doğrulamak için lenf nodları eksizyonu yapıldı. Histomorfolojik inceleme, konfluent ve ayrık dökülmeyen granülomlarla birlikte serpilmiş mononükleer Reed Sternberg hücreleri ile küçük ila orta büyüklükteki lenfoid hücreler tarafından lenf nodu mimarisinin etkinliğini göstermiştir. Ek olarak, granülomatöz enflamasyonlu nodüler lenfosit baskın Hodgkin lenfoma tanısı koyan immünohistokimyasal boyama yapıldı. Bu birliktelik nadirdir, bu nadir patolojik varlığı rapor etmemizi, özellikle granülomatöz reaksiyonla birlikte lenf nodunun dikkatli mikroskopik değerlendirilmesine vurgu yapmamızı sağlar.

Anahtar Kelimeler: Hodgkin lenfoma, Granülom, Sarkoidoz, İnce iğne aspirasyon sitolojisi

\section{INTRODUCTION}

Non necrotizing granulomas have been described in lymph node in association with various malignant disorders including Hodgkins and non Hodgkins lymphomas ${ }^{1}$. However, the recent literature fails to associate any of the subtype of HL with granulomatous inflammation. Additionally, the Indian subcontinent harbors multiple mimics of sarcoidlike reaction in the lymph node, which could pose a diagnostic dilemma for the histopathologists. Herein, we report a rare association of nodular lymphocyte predominant HL (NLPHL) with non-necrotizing granulomatous reaction. This case underscores the significance of meticulous microscopic assessment of granulomatous lymphadenitis for identifying the underlying etiology, thereby allowing the patient to obtain appropriate treatment.

\section{CASE REPORT}

A 34-year-old female who presented with swelling in right under arm for four months with no history of fever or weight in June 2018 in tertiary health care hospital Rohtak loss. Complete blood count revealed anemia, while other hematological and biochemical parameters were within normal limits. Serum calcium $(11.0 \mathrm{mg} / \mathrm{dl})$ and the serum
Angiotensin Converting Enzyme (65 U/L) levels were normal. On physical examinations, a nontender and firm swelling measuring $2 \times 2 \mathrm{~cm}$ was noted in the axilla. On radiological imaging multiple enlarged axillary lymph nodes were found with a suspicion for tuberculosis or lymphoma. FNAC of axillary swelling revealed reactive lymphadenitis. To confirm the diagnosis lymph nodes excision was performed. Patient written consent was taken prior to the procedure.

Histomorphological examination revealed effacement of lymph node architecture by neoplastic infiltrate comprising of small to intermediate sized lymphoid cells with interspersed mononuclear Reed-Sternberg (RS)-like cells along with confluent and discrete non-necrotizing granulomas (Figure 1).

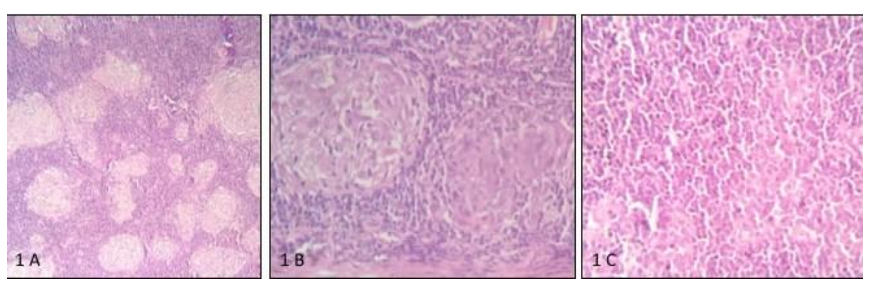

Figure 1: (1A) Section shows effacement of lymph node architecture by lymphoid cells along with discrete nonnecrotizing granulomatous inflammation(H\&E;100X); (1B) Lymphoid cells along with discrete non-necrotizing granulomatous (H\&E 200X); (1C) Mononuclear RS -like cells rimmed by lymphoid cells (H\&E: 100X) 
Furthermore immunohistochemical staining of the small and intermediate sized lymphoid cells and RS-like cells revealed positivity for CD20; however, the RS-like cells were negative for CD3, CD15 and CD30 (Figure 2).
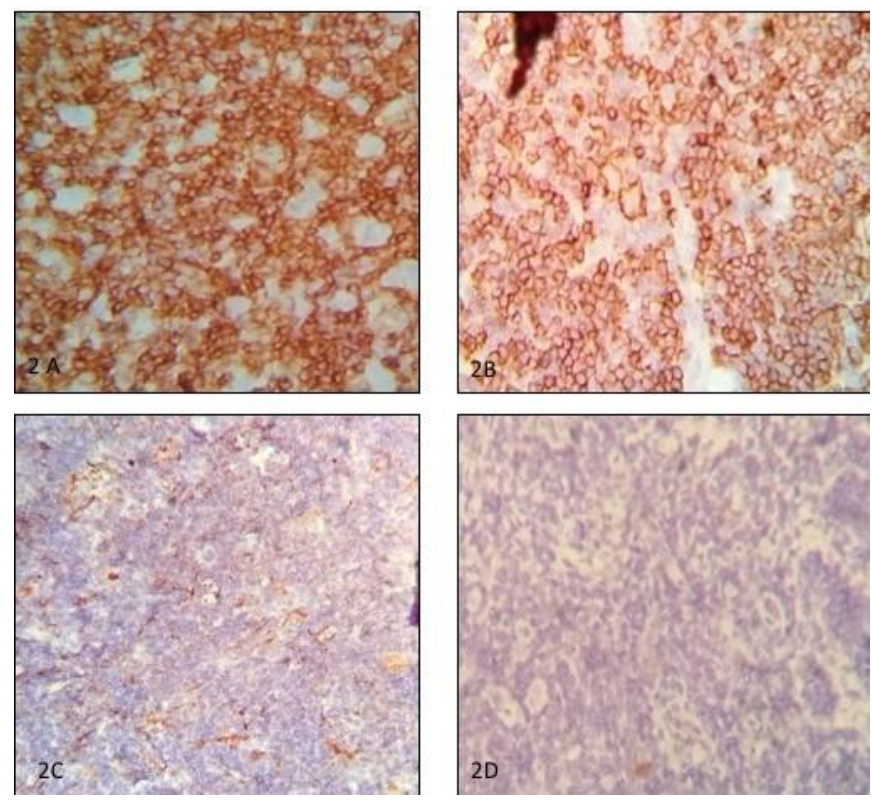

Figure 2:(2A) CD3 positive in lymphoid cells (IHC;400X); (2B) CD20 Positive in RS- like cells (IHC;400X); (2C)\& (2D) RS- like cells negative for CD15\& CD30(IHC;400X)

Thus, a diagnosis of NLPHL with sarcoid-like granuloma was rendered. Subsequently, radiotherapy was initiated and the patient is responding well.

\section{DISCUSSION}

Granulomatous inflammation is a blueprint of tissue reaction following cell injury. Broadly, it can be categorized as foreign-body giant cell and immune granulomas. Non-necrotizing (sarcoid-like) granuloma, a type of immune granuloma; is composed of aggregates of epithelioid cells with absent necrotic center. Among other causes, it is commonly encountered in malignant lymphoma such as $\mathrm{HL}^{2}$. HL is a distinct hematolymphoid neoplasm, defined by the presence of RS cells in an inflammatory milieu. The recent literature subdivides HL into classical HL and NLPHL. Merely $5 \%-10 \%$ of total HL cases, are histologically typed as NLPHL ${ }^{3,4}$. NLPHL usually unveils indolent and asymptomatic course with median age of presentation (30-40 yrs), male preponderance, strong familial risk of 1 st degree relatives and shows negativity for EBV infection ${ }^{2}$. Aberrant NF-Kappa beta activation is now recognized as critical in the development of lymphoma5. It typically shows proclivity towards peripheral (neck and / or axilla) as opposed to central (mediastinal or hilar) lymph node involvement with discontiguous nodal spread. $70-80 \%$ of patients present with stage I or II disease. B symptoms are uncommon, occurring only in $5-10 \%$ of all NLPHL patients. Bulky disease is diagnosed in $<10 \%$ of patients ${ }^{3}$.

NLPHL with non-necrotizing granulomatous inflammation is primarily diagnosed on the basis of histomorphological features which reveals nodular collections of small lymphocytes and histiocytes with interspersed large neoplastic cells called as LP cells along with presence of non-necrotizing granulomas. These malignant cells (LP cells) have multilobated nuclei with one or more nucleoli shows resemblance to kernel of popcorn and has led to term popcorn cell 5 . Often in challenging biopsies, IHC markers such as CD3, CD15, CD30 and CD20 can assist in confirmation of the diagnosis. In spite of close association ofgranulomas with lymphoma, initial detection of granulomas without concurrent evidence of malignancy leads to think of mimics of non necrotizing granulomatous inflammation, one of which most common which drives attention includes tuberculosis and confer the patients with anti- tubercular /steroids which poses diagnostic dilemma to the clinicians, and therefore to resolve this issue their arises need of careful microscopic evaluation of lymph node along with relevant investigations should be implicated in order to circumvent its transformation to advanced stage or DLBCL, as early stage NLPHL has favorable prognosis and greater overall survival index than CHL.6,7As per literature one study reported by Konkey et 
al on total of 196 subjects of HL have reported an incidence of granulomas in $6.6 \%$ cases of NLPHL $^{8}$.

Investigations pertaining to the staging of NLPHL should at least include: a full patient history, physical examination, Complete blood count, LFT and KFT, lactate dehydrogenase assay, serum electrolyte assay, CT scan of neck, chest, abdomen and pelvis. Other imaging modalities such as MRI, bone scanning and $18 \mathrm{~F}$ FDG helps in detecting areas of high grade transformation ${ }^{9}$. In the present case, initial clinical and laboratory work-up favored the diagnosis of NLPHL with sarcoid like granulomas. As per literature due to this meager percentage of cases reported so far of NLPHL with non-necrotizing inflammation thereby making us pertinent for reporting this rare pathological entity. The histologic identification of granulomatous inflammation is a helpful predictor of diagnostic aetiology based on their histologic patterns (foreign-body, necrotizing, non-necrotizing, suppurative, and a diffuse histiocytic reaction). Although the aetiology of sarcoidosis is unknown, there is evidence that this disorder is associated with a dysfunction of the immune system, which may play a key pathogenetic role in this disease predisposing the secondary lymphoid malignancy as in our case ${ }^{2}$.

NLPHL is commonly staged as early stage (stage I/II) or advanced stage (III/IV). Both these stages have different prognostic implications and therapeutic protocols. Nonetheless, staging ultimately aims to identify the disease transformation to DLBCL. In early stage of disease we prefer either radiotherapy alone. The main stay of treatment of advanced NLPHL with non-necrotizing granulomatous inflammation is multiagent combination like ABVD and CHOP in combination with rituximab ${ }^{2}$.With the advent of newer therapeutics agents, it leads to favorable prognosis of NLPHL patients but it also ensues need of better diagnostic guidelines for treating these rare pathological entities.

\section{CONCLUSION}

NLPHL with sarcoid like granulomas has its uniqueness because it is a rare entity with only few cases reported in literature so far. This case emphasizes on careful evaluation of lymph node architecture to rule out any obscured malignancy. An early detection of this rare pathological entity improves clinical outcome and overall patient survival.

Informed Voluntary Consent Form: Consent form was taken from the patient.

Declaration of conflicting Interest: The authors declare that have no conclift of interest.

Financial Disclosure: No financial support was received.

\section{REFERENCES}

1. Pai K, Sharma S, Padmapriya J. Florid granulomatous response masking diagnosis of Hodgkin's disease in FNA cytology: a diagnostic challenge. Int J Health Sci Res. 2015; 5:468-470.

2. Shanbhag $S$, Ambinder RF. Hodgkin Lymphoma: A Review and update on Recent Progress. CA Cancer J Clin.2018;68:116-32.doi: 10.3322/caac.21438 PMID: 29194581

3. Lee AI, Lacasce AS. Nodular lymphocyte predominant Hodgkin Lymphoma.The Oncologist.2009;14:739-51. PMID:19605845 DOI:10.1634/theoncologist 2009-0099.

4. Shah KK, Pritt BS, Alexander MP.Histopathological review of granulomatous inflammation. Journal of Clinical Tuberculosis and other Mycobacterial Diseases.2017;7:1-12. http://dx.doi.org/10.1016/j.jctube.2017.02.00 1

5. Shankar A, Daw S. Nodular lymphocyte predominant Hodgkin lymphoma in children and adolescents - a comphrensive review of biology. clinical course and treatment 
options.Bri J Haematol. 2012:288-98. doi: 10.1111/bjh.12055 PMID: 22994199

6. Aggarwal P, Sharma M, Nimbran V, Kaur K. Hodgkin lymphoma with granulomas. Demystifying The Dilemma. Annals of Pathol and Lab Med. 2018;5. Doi:10.21276/APALM.1861

7. Gerber NK, Atoria CL, Elkin EB, Yshalom J. Characteristics and outcomes of patients with nodular lymphocyte predominant Hodgkin lymphoma versus those with classical Hodgkin lymphoma : A population based analysis. Int J Radiation Oncol Biol Phys. 2015;92:76-83. http://dx.doi.org/10.1016/j.ijrobp2015.02.012
8. Konkay K, Paul TR, Uppin S, Rao DR. Hodgkin lymphoma: A clinicopathological and immunophenotypic study. Indian J Med Paediatr Oncol 2016;37:59-65. DOI: 10.4103/0971-5851.177038

9. Mckay P, Fielding P, Evans EG, et al. Guidelines for the investigation and management of nodular lymphocyte predominant Hodgkin lymphomas. Br J Haematol.2016;172:32-43.doi: 10.1111/bjh.13842 PMID: 26538004 